\title{
Martensitic Stainless Steels Low-temperature Nitriding: Dependence of Substrate Composition
}

\author{
Lauro Mariano Ferreira ${ }^{a}$, Silvio Francisco Brunatto ${ }^{a}$, Rodrigo Perito Cardoso ${ }^{a *}$
}

\author{
${ }^{a}$ Laboratório de Tecnologia de Pós e Plasma, Departamento de Engenharia Mecânica, \\ Universidade Federal do Paraná - UFPR, Centro Politécnico, CEP 81531-980, Curitiba, PR, Brazil
}

Received: April 8, 2015; Revised: April 26, 2015

\begin{abstract}
Low-temperature plasma assisted nitriding is a very promising technique to improve surface mechanical properties of stainless steels, keeping unaltered or even improving their surface corrosion resistance. During treatment, nitrogen diffuses into the steel surface, increasing its hardness and wear resistance. In the present work the nitriding process of different martensitic stainless steels was studied. As-quenched AISI 410, 410NiMo, 416 and 420 stainless steel samples were plasma nitrided at 300, $350,400,450$, and $500^{\circ} \mathrm{C}$, for $4 \mathrm{~h}$, at 3 Torr, in a gas mixture of $70 \% \mathrm{~N}_{2}+20 \% \mathrm{H}_{2}+10 \% \mathrm{Ar}$, and flow rate of $3.33 \times 10^{-6} \mathrm{Nm}^{3} \mathrm{~s}^{-1}$. The study of the nitrogen-rich layer thickness indicates two different activation energies, one for low $\left(<400^{\circ} \mathrm{C}\right)$ and another one for high temperature $\left(\geq 400^{\circ} \mathrm{C}\right)$, except for the AISI 410 NiMo. The surface hardness increases with temperature for all steels between 300 and $450^{\circ} \mathrm{C}$. For $500^{\circ} \mathrm{C}$, except for the AISI $410 \mathrm{NiMo}$, the surface hardness decreases if compared to that obtained at $450^{\circ} \mathrm{C}$. This hardness decrease is related to chromium nitride precipitation, also associated to the treated surface sensitization. Finally, the $\mathrm{CrN}$ precipitation in treated surfaces is dependent on the steel composition, with the AISI 410NiMo steel presenting the lower average chromium nitride precipitation rate.
\end{abstract}

Keywords: low-temperature plasma nitriding, martensitic stainless steel, nitrided layer growth, composition dependence

\section{Introduction}

Martensitic stainless steels are usually applied for producing parts subjected to high mechanical stress and operating in corrosive environment. For applications demanding high wear resistance the properties of such steels are frequently insufficient, so surface treatment like nitriding or carburizing can be applied to improve the component surface properties ${ }^{1-6}$. For this purpose, lowtemperature plasma-assisted techniques is among of the most studied techniques for this steel class. If processing parameters are conveniently chosen, it is possible to obtain a treated surface presenting higher hardness and corrosion resistance than the untreated surface ${ }^{7-14}$. However, if the process parameters are not correctly selected, the treated surface can present a corrosion resistance lower than that expected for the bulk material after adequate solution treatment, which must be strongly avoided particularly on the case of stainless steels.

Considering low-temperature plasma-assisted nitriding and carburizing of stainless steels, it can be affirmed that the treatment of austenitic stainless steels was extensively studied. On the other hand, studies for martensitic stainless steels have been less considered, and several opened questions remain to be answered. Among the several parameters to be chosen and controlled, it is well known that the substrate composition plays an important role on the low-temperature

*e-mail: rodrigo.perito@ufpr.br thermochemical treatment of austenitic stainless steels ${ }^{15-17}$. Those authors have shown that the presence of copper and molybdenum in solid solution allowed higher content of carbon/nitrogen in the layer of the supersaturated expanded austenite, at the treated surface, in the studied austenitic stainless steels. The suggested mechanism to enable a higher carbon/nitrogen supersaturation, the lattice expansion effect due to larger elements, is also expected to play a significant role on the case of martensitic stainless steels. During the bibliographic review concerning low-temperature nitriding of martensitic stainless steels, papers on, for example, the influence of the treating temperature ${ }^{6}$, the influence of nitriding process on wear ${ }^{11,12}$, and corrosion resistance ${ }^{1,2,11}$ of the treated samples, were found. However, no work was found dealing with the present subject, despite its evident technological importance. So, the aim of this work is to study the nitriding process of martensitic stainless steels with different composition, focusing in two important kinetic aspects:

i) the nitrided layer growth/thickness, mainly related to the mechanical properties of the layer; and;

ii) the chromium nitride precipitation process (sensitization), mainly related to the corrosion resistance of the treated surface, but also related to its mechanical properties. 


\section{Experimental Procedure}

Cylindrical samples of $9.5 \mathrm{~mm}$ in diameter and $5 \mathrm{~mm}$ height were cut from commercial AISI 410, 416 and 420 martensitic stainless steels bars. The AISI 410NiMo samples were square pieces of $10 \mathrm{~mm} \times 10 \mathrm{~mm} \times 2 \mathrm{~mm}$, being prepared by cutting and cold forming of welding wire. One of the main differences among the AISI 410, 410NiMo, 416 and 420 is the carbon content (in this work related to the evaluation of interstitial atoms content influence), whereas the AISI 410 and AISI 410NiMo present additional difference in the $\mathrm{Ni}$ and Mo content (referred to the evaluation of substitutional atoms content influence). Table 1 presents the compositions of the studied steels, according to the steel manufacturer certificates. Quenching of the different studied steels was carried out accordingly to the treatment parameters indicated by $\mathrm{ASTM}^{18}$. As a general rule, the higher value of each typical austenitizing temperature range for each steel was specified to guarantee higher degree of homogenization of austenite. For all cases, an austenitizing time of $0.5 \mathrm{~h}$ was used. Finally, AISI 410, 410NiMo, and 420 steel samples were air-quenched, whereas AISI 416 samples were oil-quenched. After quenching all samples were ground and mirror-polished using $1 \mu \mathrm{m} \mathrm{Al}_{2} \mathrm{O}_{3}$ suspension and cleaned with alcohol in ultrasonic bath.

In the present work, tempering of the as-quenched samples was carried out simultaneously to the plasma nitriding treatment. Nitriding was carried out at $300,350,400,450$, and $500^{\circ} \mathrm{C}$, for a time of $4 \mathrm{~h}$. In the absence of hot wall, heating of the samples was achieved by plasma species bombardment only.
The cathode assemblage of each nitriding treatment consisted of one sample of each studied steel symmetrically placed on the same sample holder. The plasma was generated by a $4.2 \mathrm{kHz}$ square-wave pulsed DC power supply set at $700 \mathrm{~V}$ peak voltage. The treatment temperature was measured by means of a $\mathrm{K}$ type thermocouple, inserted $8 \mathrm{~mm}$ in depth on the center of the sample holder, and controlled by adjusting the duty cycle of the power supply through the switched-on pulse time $\left(\mathrm{t}_{O N}\right)$. Gas mixture and flow rate were controlled by three mass flow controllers $\left(8.33 \times 10^{-6} \mathrm{Nm}^{3} \mathrm{~s}^{-1}\right.$ at full scale operation) and fixed at $70 \% \mathrm{~N}_{2}+20 \% \mathrm{H}_{2}+10 \% \mathrm{Ar}$, and $3.33 \times 10^{-6} \mathrm{Nm}^{3} \mathrm{~s}^{-1}$, respectively. The pressure, fixed for all treatments at 3 Torr, was measured by means of a capacitive manometer (10 Torr full scale) and controlled by an automated throttle valve. After introducing samples into the vacuum chamber, it was evacuated to a residual pressure of $10^{-2}$ Torr using a double stage mechanical pump. Before nitriding, samples were sputter-cleaned at $300^{\circ} \mathrm{C}$, during $0.5 \mathrm{~h}$, using a $80 \% \mathrm{H}_{2}+20 \%$ Ar gas mixture, at 3 Torr, for a gas flow rate of $3.33 \times 10^{-6} \mathrm{Nm}^{3} \mathrm{~s}^{-1}$. A schematic representation of the experimental apparatus used in present work is presented in Figure 1.

The treated layers microstructure was characterized by optical microscopy after standard metallographic preparation and etching with Marble's reagent $\left(4 \mathrm{~g} \mathrm{CuSO}_{4}+20 \mathrm{cc} \mathrm{HCl}+20 \mathrm{cc} \mathrm{H}_{2} \mathrm{O}\right)$. Optical micrograph technique, using $1000 \times$ magnification, was used to determine the nitrided layer thickness. The shown values represent the means of at least five measurements taken in five different regions of the samples. Microhardness measurements were performed using a Vickers indenter

Table 1. Steel composition according to the steel manufacturer certificate.

\begin{tabular}{|c|c|c|c|c|c|c|c|c|}
\hline \multirow{2}{*}{ Steel } & \multicolumn{8}{|c|}{ Composition (wt.\%) } \\
\hline & $\mathbf{C}$ & Si & Mn & $\mathrm{Cr}$ & $\mathbf{N i}$ & Mo & $\mathbf{P}$ & $\mathbf{S}$ \\
\hline AISI 410 & 0.11 & 0.42 & 0.76 & 12.3 & 0.36 & 0.03 & 0.028 & 0.016 \\
\hline AISI 416 & 0.13 & 0.32 & 0.98 & 12.3 & 0.39 & 0.08 & 0.028 & 0.180 \\
\hline AISI 420 & 0.32 & 0.55 & 0.46 & 12.3 & 0.15 & 0.00 & 0.026 & 0.024 \\
\hline AISI 410 NiMo & 0.02 & 0.38 & 0.66 & 11.9 & 4.50 & 0.40 & 0.020 & 0.001 \\
\hline
\end{tabular}

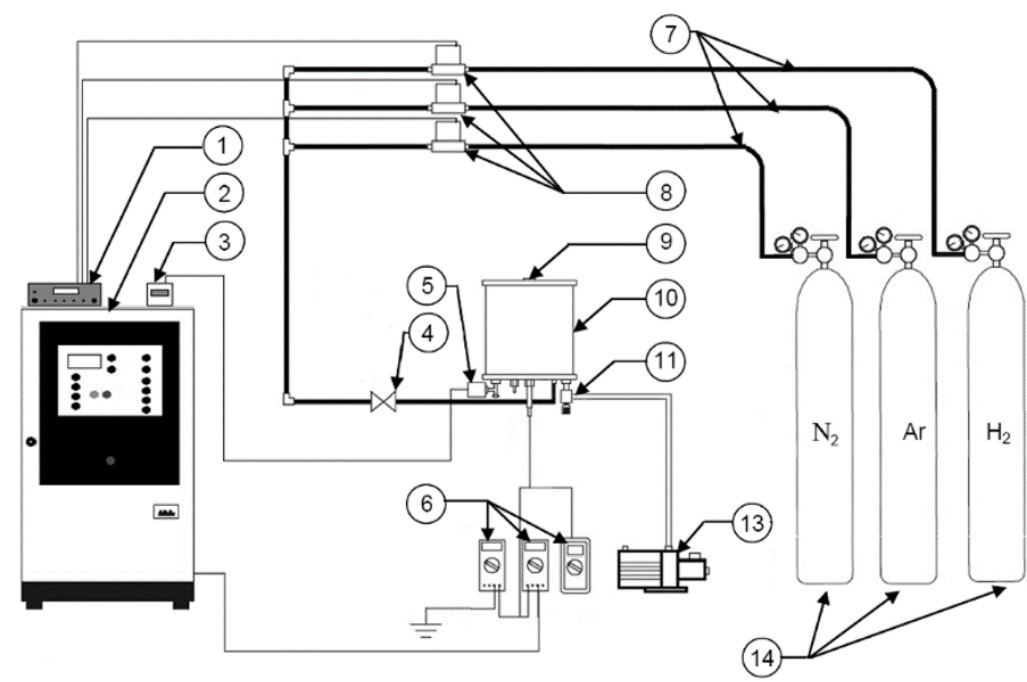

1 - Mass flow control unit

2 - Power supply

3 - Digital pressure display

$4-$ Gas valves

5 - Capacitive manometer

6 - Multimeters

7 - Gas lines

8 - Thermal mass flow controllers

9 - Viewing window

10 - Vacuum chamber

11 - Vacuum valve

12 - Manometers

13 - Vacuum pump

14 - Gas cylinders

Figure 1. Scheme of the low-temperature plasma nitriding experimental apparatus. 
applying a $0.300 \mathrm{kgf}$ load during $15 \mathrm{~s}$, each measurement was repeated at least 5 times, respecting a distance of $2 \mathrm{~mm}$ between two neighbor measurements. Finally, in order to characterize the phases formed on the surface during plasma nitriding, X-ray diffraction (XRD) analysis was performed in the Bragg-Brentano configuration using $\mathrm{CuK} \alpha$ radiation.

\section{Results and Discussion}

Cross-section micrographs of the AISI 416 samples treated at different temperatures are presented in Figure 2. Nitrided layers presenting different microstructures in relation to unaltered bulk material can be observed at the treated surfaces. The treated layer becomes thicker as the treatment temperature is increased. It is possible to note that the treated layer microstructure also changes accordingly to temperature. White-aspect layers can be observed at lower temperatures (Figures 2a, b), whereas the presence of a second dark-aspect microconstituent gradually becomes more and more evident, all over the nitrided layer, at higher temperatures (Figures 2c-e). These dark regions are attributed to the sensitization (localized reduction of the corrosion resistance) of the treated layer due to $\mathrm{CrN}$ (chromium nitride) precipitation, occurring predominantly at high temperatures. Since $\mathrm{Cr}$ atoms present low mobility at the studied temperatures, $\mathrm{CrN}$ formation is more probable than $\mathrm{Cr}_{2} \mathrm{~N}$, considering that it presents less chromium in its composition. If carefully analyzed, slight sensitization at the grain boundaries started at $400^{\circ} \mathrm{C}$, as it can be observed in Figure 2c microstructure. This aspect will be discussed in more detail hereafter in this section. Concerning the AISI 410, 410NiMo, and 420 treated samples, the same qualitative microstructural evolution as a function of the nitriding temperature was observed. Since the AISI 416 is a free-cutting stainless steel grade, manganese sulphide inclusions (gray regions) can also observed in the bulk material (Figures 2 and 3c).

The cross-section micrographs of the AISI 410, 410NiMo, 416 , and 420 samples treated at $450^{\circ} \mathrm{C}$ are presented in Figures 3a-d, respectively. This temperature was chosen since it makes easier to differentiate the degree of sensitization among the different studied steels. Results show that AISI 410 , and 416 (Figures $3 \mathrm{a}, \mathrm{c}$ ) are more sensitized than the AISI $410 \mathrm{NiMo}$, and 420 (Figures 3b, d) steels. Comparing AISI 410 NiMo and 420 (Figures 3b, d) steels, no effective difference can be noted in the related nitrided layer microstructures. Aiming to determine if there is some difference in this case, XRD analysis was carefully realized, as discussed further on.

The Arrhenius plot of the nitrided layer thickness for the different studied steels is presented in Figure 4 (being the layer thickness values also presented on Table 2). From Figure 4, it can be observed that the layer thickness is similar for all studied steels at high temperatures $\left(400-500^{\circ} \mathrm{C}\right)$, presenting approximately the same process activation energy (proportional to the Arrhenius plot slope). For low temperatures $\left(<400^{\circ} \mathrm{C}\right)$, the AISI 410, 416 and 420 steels tend to have lower process activation energy than that observed at high temperature. In this case, high-diffusivity paths could be considered as an important factor to explain the layer growth at low

Table 2. Nitrided layer thickness for all studied steels and temperatures.

\begin{tabular}{lccccc}
\hline \multicolumn{6}{c}{ Nitrided layer thickness $(\boldsymbol{\mu m})$} \\
\hline \multirow{5}{*}{ Steel } & \multicolumn{5}{c}{ Treatment temperature $\left({ }^{\circ} \mathbf{C}\right)$} \\
\cline { 2 - 6 } & $\mathbf{3 0 0}$ & $\mathbf{3 5 0}$ & $\mathbf{4 0 0}$ & $\mathbf{4 5 0}$ & $\mathbf{5 0 0}$ \\
\hline AISI 410 & $3.4 \pm 0.2$ & $6.3 \pm 0.2$ & $15.6 \pm 0.4$ & $26.2 \pm 0.5$ & $50.4 \pm 0.7$ \\
AISI 416 & $4.0 \pm 0.2$ & $6.9 \pm 0.6$ & $13.5 \pm 0.3$ & $28.9 \pm 0.5$ & $52.6 \pm 0.5$ \\
AISI 420 & $3.6 \pm 0.2$ & $5.6 \pm 0.3$ & $14.6 \pm 0.2$ & $28.6 \pm 0.4$ & $53.5 \pm 0.8$ \\
AISI 410 NiMo & $1.8 \pm 0.1$ & $4.9 \pm 0.4$ & $14.4 \pm 0.4$ & $27.3 \pm 0.4$ & $52.8 \pm 0.3$ \\
\hline
\end{tabular}
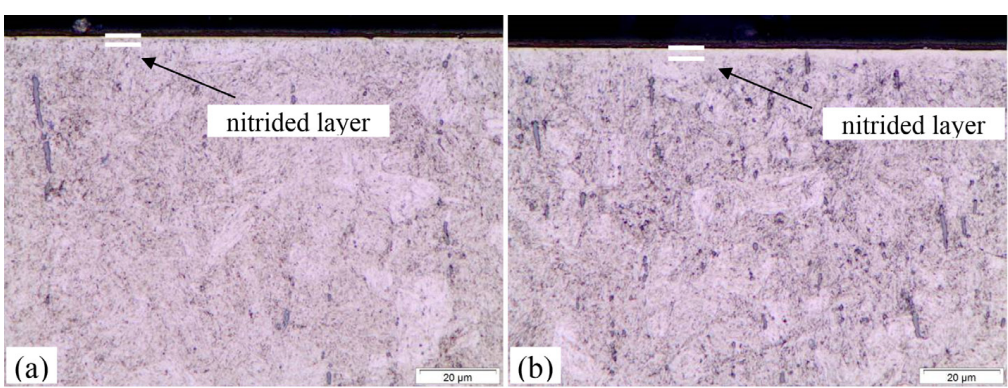

(b)

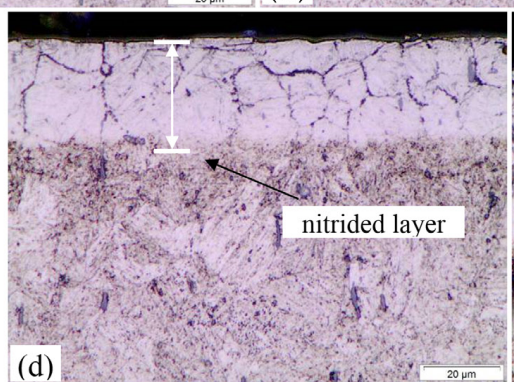

(d)

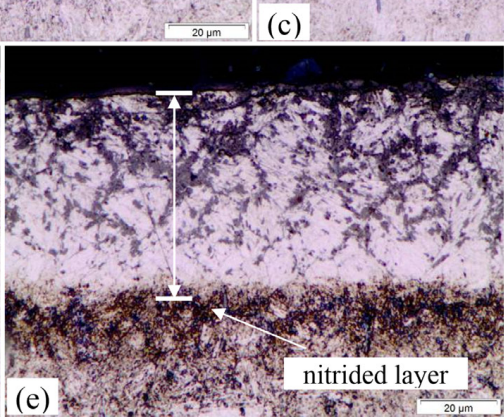

Figure 2. Cross-section micrographs of AISI 416 samples nitrided at: (a) 300, (b) 350, (c) 400, (d) 450, and (e) $500^{\circ} \mathrm{C}$. Treatments carried out for $4 \mathrm{~h}$, using a gas mixture composition of $70 \% \mathrm{~N}_{2}+20 \% \mathrm{H}_{2}+10 \% \mathrm{Ar}$, at a flow rate of $3.33 \times 10^{6} \mathrm{Nm}^{3} \mathrm{~s}^{-1}$ and pressure of 3 Torr. 

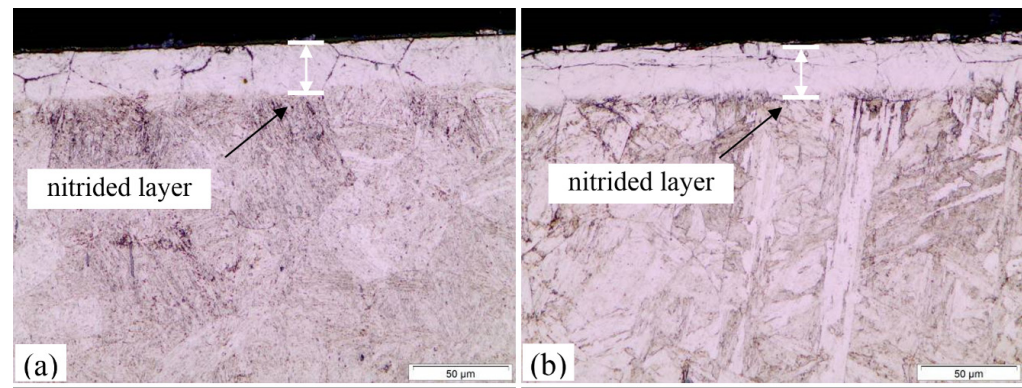

(a)
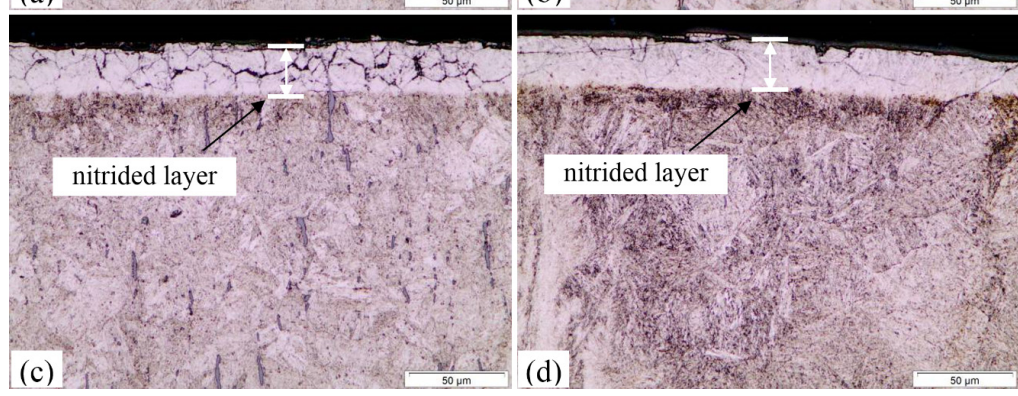

Figure 3. Cross-section micrographs of samples nitrided at $450^{\circ} \mathrm{C}$ : (a) AISI 410, (b) AISI 410NiMo, (c) AISI 416, and (d) AISI 420. Treatments carried out for $4 \mathrm{~h}$, using a gas mixture composition of $70 \% \mathrm{~N}_{2}+20 \% \mathrm{H}_{2}+10 \% \mathrm{Ar}$, at a flow rate of $3.33 \times 10^{6} \mathrm{Nm}^{3} \mathrm{~s}^{-1}$ and pressure of 3 Torr.

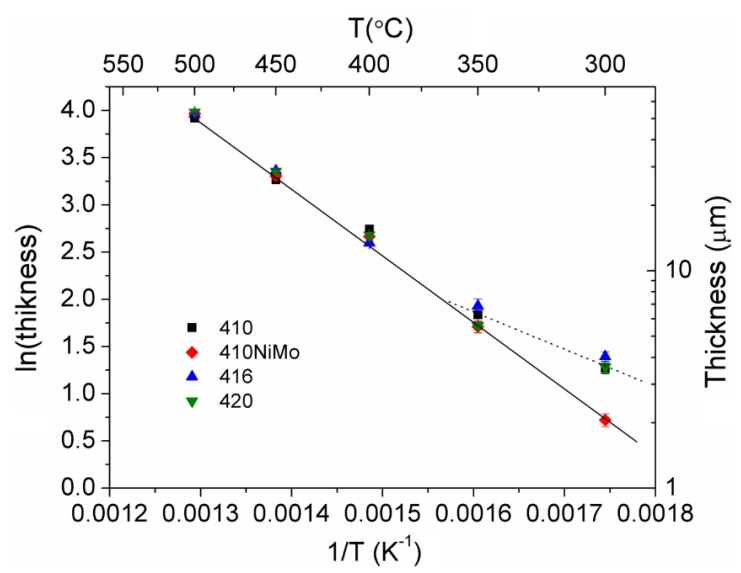

Figure 4. Arrhenius plot for the nitrided layer thickness for all studied steels and temperatures. Treatments carried out for $4 \mathrm{~h}$, using a gas mixture composition of $70 \% \mathrm{~N}_{2}+20 \% \mathrm{H}_{2}+10 \% \mathrm{Ar}$, at a flow rate of $3.33 \times 10^{6} \mathrm{Nm}^{3} \mathrm{~s}^{-1}$ and pressure of 3 Torr.

temperature. On the other hand, the AISI 410NiMo steel does not present the same slope variation, as observed for the other steels, showing that the process activation energy was about the same for samples nitrided at "high" and "low" temperatures. Comparing the bulk material microstructures it can be noticed that the AISI 410NiMo steel samples present relative coarser structure, which would reduce the role of high-diffusivity paths on the nitrided layer growth, in this case, to a level that it is not detectable with the applied measurement techniques. In addition, considering the well known effect of lattice expansion regarding the alloying element Mo in steel composition, according to ${ }^{15,16}$, a higher treatment kinetics should be expected for the AISI $410 \mathrm{NiMo}$ steel. Nevertheless, it seems that in our case, the effect of high-diffusivity paths overcomes the Mo effect, differently to the observed by ${ }^{15,16}$ on the layer growth kinetics of austenitic stainless steels. Albeit the presence o Mo and Ni does not influence significantly the layer growth for the studied steels and treatment conditions, it is possible that the presence of large elements like molybdenum could improve the interstitial atoms content (in our case nitrogen) in solid solution, changing the nitrided layer characteristics and properties, as it will be presented in Figures 5 and 6. Summarizing, for the cases studied in this work, there is a simultaneous influence of the composition and the presence of high-diffusivity paths. But, in the studied range of temperature $\left(300-500^{\circ} \mathrm{C}\right.$ for a fixed treatment time of $4 \mathrm{~h}$ ), the presence of high-diffusivity paths seems to be more important than the composition variation concerning the layer growth kinetics.

The surface and bulk hardness of the treated samples is presented in Figure 5a. For all studied temperatures and steels the surface hardness is higher than the bulk material, indicating that in all cases nitrogen was introduced in the treated surface. Given that tempering occurs simultaneously to nitriding, the bulk hardness slightly decreases with nitriding temperature, as expected for tempering treatment to the majority of steels. On the other hand, regarding the surface hardness, it increases from 300 to $450^{\circ} \mathrm{C}$ for all studied steels. But, from 450 to $500^{\circ} \mathrm{C}$, the surface hardness of the AISI 410, 416 and 420 decreases while it remains approximately constant for the AISI $410 \mathrm{NiMo}$. The related effect in AISI 410NiMo steel could also be attributed to a possible lower level of chromium nitride precipitation, as verified and already discussed in Figure 3. The chromium nitride precipitation reduces the nitrogen content in the expanded-martensite and consequently its hardness, having this phase an important hole on the mechanical properties of the treated layer. Aiming to better understanding this point, Figure $5 \mathrm{~b}$ shows the hardness difference between the nitrided surface and the respective sample bulk. Results clearly show that the hardening effect tends to be higher for 


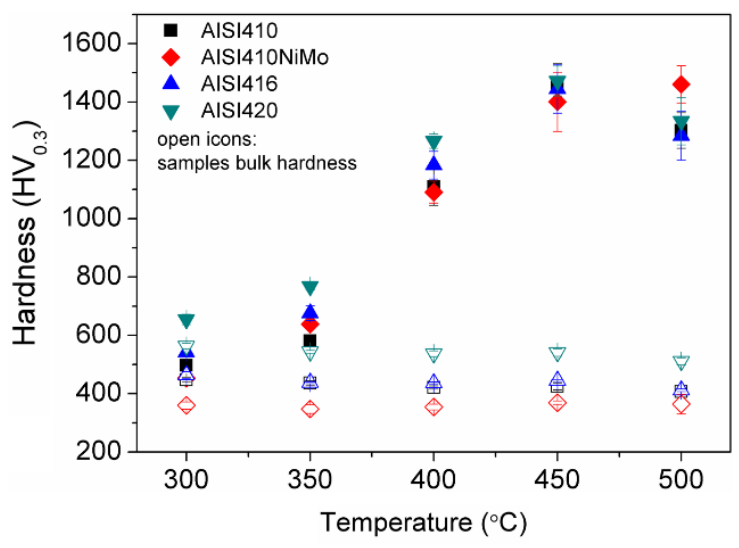

(a)

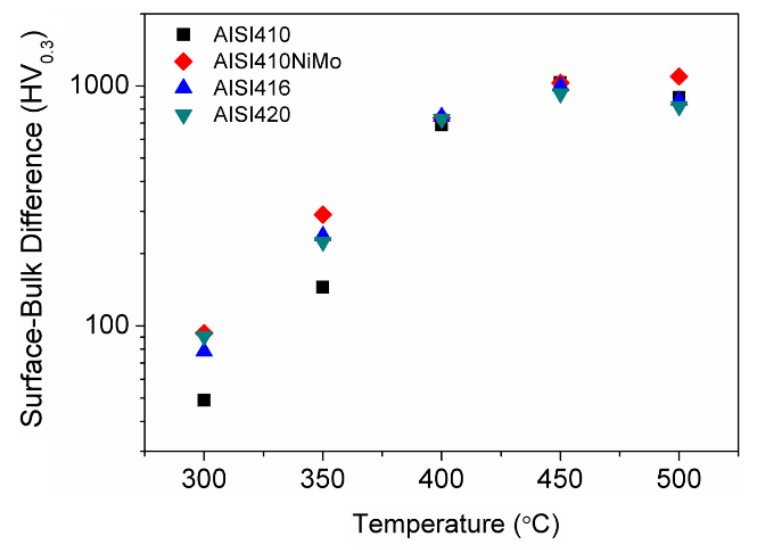

(b)

Figure 5. (a) Hardness of the nitrided surface (filled icons), and sample bulk (opened icons) for all studied steels and temperatures; and (b) the related (nitrided)surface-bulk(of the sample) hardness difference. Treatments carried out for $4 \mathrm{~h}$, using a gas mixture composition of $70 \% \mathrm{~N}_{2}+20 \% \mathrm{H}_{2}+10 \% \mathrm{Ar}$, at a flow rate of $3.33 \times 10^{6} \mathrm{Nm}^{3} \mathrm{~s}^{-1}$ and pressure of 3 Torr.

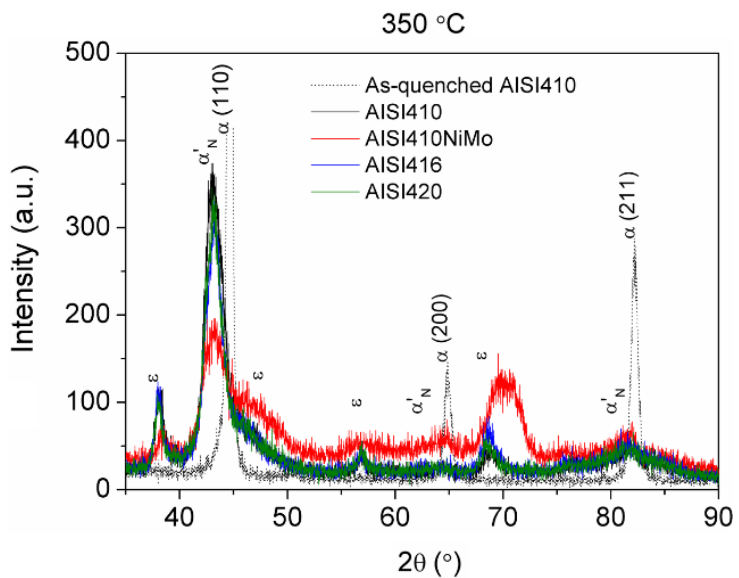

(a)

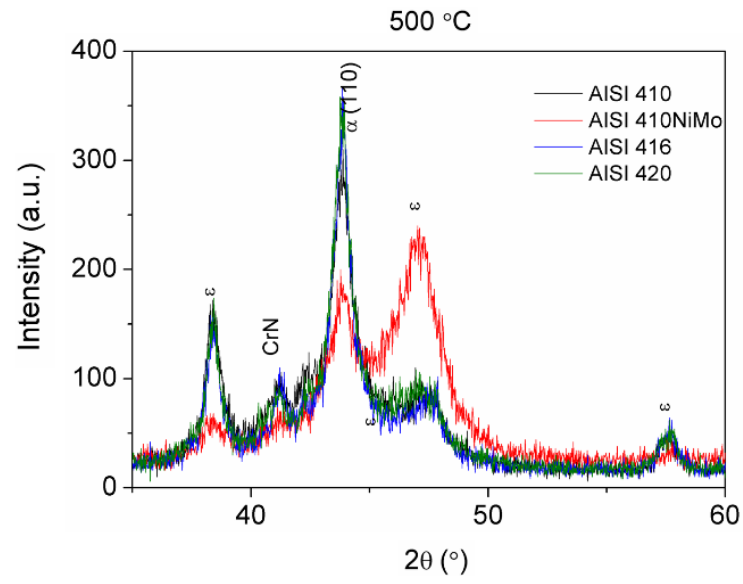

(b)

Figure 6. X-ray diffraction patterns of all studied steels nitrided at: (a) $350^{\circ} \mathrm{C}$; and (b) $500^{\circ} \mathrm{C}$. Treatments carried out for 4 h, using a gas mixture composition of $70 \% \mathrm{~N}_{2}+20 \% \mathrm{H}_{2}+10 \% \mathrm{Ar}$, at a flow rate of $3.33 \times 10^{6} \mathrm{Nm}^{3} \mathrm{~s}^{-1}$ and pressure of 3 Torr.

the AISI $410 \mathrm{NiMo}$ steel, even for the treatment at $300^{\circ} \mathrm{C}$, for which the layer thickness was about half than those obtained to the other studied steels. So, to finish the discussion on this point, lattice expansion effect due to the presence of Mo, as suggested by ${ }^{15-16}$, could also be responsible for the increase of the layer hardness. For technological purposes this aspect merits to be further studied, but it is out of the scope of the present work.

Finally, the XRD patterns of the studied surfaces are presented in Figure 6. For low temperature (in the case, $350^{\circ} \mathrm{C}$ - Figure $\left.6 \mathrm{a}\right)$, the nitrided surface is mainly composed of $\varepsilon-\mathrm{Fe}_{2-3} \mathrm{~N}$ nitride and $\mathrm{N}$-expanded martensite $\left(\alpha_{\mathrm{N}}{ }_{\mathrm{N}}\right)$ phases. Equivalent XRD patterns were observed for steels presenting different initial interstitial contents, being the case of the AISI 410, 416, and 420 steels. Differently, when the composition variation is also due to substitutional atoms (being the case of AISI 410, and 410NiMo steel samples) the XRD patterns present significant differences. For high temperature (in the case, $500^{\circ} \mathrm{C}$ - Figure $6 \mathrm{~b}$ ), the peak of $\mathrm{N}$-expanded martensite
$\left(\alpha_{\mathrm{N}}\right)$ tends to disappear and a peak of $\mathrm{CrN}$, which was related to the sensitization observed in Figures 2 and 3, can be also observed. At this point it is worth to be noticed that the peak o $\mathrm{CrN}$ is less intense for the AISI 410NiMo steel, being in agreement with its lower degree of surface sensitization, as observed in Figure 3, and with its higher hardness at the highest studied temperature (Figure 5).

\section{Conclusion}

The influence of the martensitic stainless steels composition on the nitriding process was carried out by treating four different kind of steels. Three of them, the AISI 410, 416 and 420, presented very similar results, indicating that the carbon content has low influence on the obtained nitrided layers. On the other hand, the AISI $410 \mathrm{NiMo}$, containing 4.5 wt.\% $\mathrm{Ni}$ and 0.4 wt.\% Mo, presented significant differences on hardness and on the relative quantity of chromium nitride precipitation, which 
was mainly attributed to the $\mathrm{CrN}$ precipitation process. In this case, the possibility of using high treatment temperatures to obtain precipitation free nitrided layers should be considered, leading the steel to be successfully nitrided at higher temperatures, additionally resulting in thicker layers. Finally, it was concluded that the initial composition of the studied steels does not significantly influence the nitrided layer thickness, since the observed differences seem to be mostly related to the presence of high-diffusivity paths,

\section{References}

1. Figueroa CA, Alvarez F, Zhang Z, Collins GA and Short KT. Structural modifications and corrosion behavior of martensitic stainless steel nitrided by plasma immersion ion implantation. Journal of Vacuum Science \& Technology. A, Vacuum, Surfaces, and Films. 2005; 23(4):693-698. http:// dx.doi.org/10.1116/1.1931681.

2. Isfahany NA, Saghafian H and Borhani G. The effect of heat treatment on mechanical properties and corrosion behavior of AISI420 martensitic stainless steel. Journal of Alloys and Compounds. 2011; 509(9):3931-3936. http://dx.doi.org/10.1016/j. jallcom.2010.12.174.

3. Kim SK, Yoo JS, Priest JM and Fewell MP. Characteristics of martensitic stainless steel nitrided in a low pressure RF plasma. Surface and Coatings Technology. 2003; 163-164:380-385. http://dx.doi.org/10.1016/S0257-8972(02)00631-X.

4. Allenstein AN, Lepienski CM, Buschinelli AJA and Brunatto SF. Plasma Nitriding of CA-6NM Steel: effect of H2+ N2 gas mixturesin nitride layer formation for low $\mathrm{N} 2$ contents at $500^{\circ} \mathrm{C}$. Materials Research. 2010; 13(4):557-562. http://dx.doi. org/10.1590/S1516-14392010000400020.

5. Alphonsa I, Chainani A, Raole PM, Ganguli B and John PI. A study of martensitic stainless steel AISI 420 modified using plasma nitriding. Surface and Coatings Technology. 2002; 150(23):263-268. http://dx.doi.org/10.1016/S0257-8972(01)01536-5.

6. Pinedo CE and Monteiro WA. On the kinetics of plasma nitriding a martensitic stainless steel type AISI 420. Surface and Coatings Technology. 2004; 179(2-3):119-123. http://dx.doi.org/10.1016/ S0257-8972(03)00853-3.

7. Zhang ZL and Bell T. Structure and corrosion resistance of plasma nitrided stainless steel. Surface Engineering. 1985; 1(2):131-136. http://dx.doi.org/10.1179/sur.1985.1.2.131.

8. Ichii K, Fujimura K and Takase T. Structure of the ion-nitrided layer of 18-8 stainless steel. Technology Reports of Kansai University. 1986; 27:135-144.

9. Nascimento FC, Foerster CE, Silva SLR, Lepienski CM, Siqueira CJM and Alves C Jr. A comparative study of mechanical and tribological properties of AISI-304 and AISI-316 submitted to being the most important influence of the composition supposedly related to the $\mathrm{CrN}$ precipitation kinetics.

\section{Acknowledgements}

This work was supported by CNPq, CAPES and Programa Interdisciplinar de Petróleo e Gás Natural da UFPR (PRH24). The authors also wish to express their thanks to the Laboratory of X-ray Optics and Instrumentation - UFPR by the use of the X-ray diffraction equipment.

glow discharge nitriding. Materials Research. 2009; 12(2):173180. http://dx.doi.org/10.1590/S1516-14392009000200011.

10. Menthe E, Rie KT, Schultze JW and Simson S. Structure and properties of plasma-nitrided stainless steel. Surface and Coatings Technology. 1995; 74-75:412-416. http://dx.doi. org/10.1016/0257-8972(95)08246-8.

11. Xi YT, Liu DX and Han D. Improvement of corrosion and wear resistances of AISI 420 martensitic stainless steel using plasma nitriding at low temperature. Surface and Coatings Technology. 2008; 202(12):2577-2583. http://dx.doi.org/10.1016/j. surfcoat.2007.09.036.

12. Xi YT, Liu DX, Han D and Han ZF. Improvement of mechanical properties of martensitic stainless steel by plasma nitriding at low temperature. Acta Metallurgica Sinica. 2008; 21(1):21-29. http://dx.doi.org/10.1016/S1006-7191(08)60015-0.

13. Mendes AF, Scheuer CJ, Joanidis IL, Cardoso RP, Mafra M, Klein AN, et al. Low-temperature plasma nitriding of sintered PIM 316L austenitic stainless steel. Materials Research. 2014; 17:100-109. http://dx.doi.org/10.1590/S1516-14392014005000064.

14. Li CX and Bell T. Corrosion properties of active screen plasma nitrided 316 austenitic stainless steel. Corrosion Science. 2004; 46(6):1527-1547. http://dx.doi.org/10.1016/j.corsci.2003.09.015.

15. Tsujikawa M, Egawa M, Ueda N, Okamoto A, Sone T and Nakata K. Effect of molybdenum and copper on S-phase layer thickness of low-temperature carburized austenitic stainless steel. Surface and Coatings Technology. 2008; 202(22-23):5488-5492. http://dx.doi.org/10.1016/j.surfcoat.2008.06.096.

16. Tsujikawa M, Noguchi S, Yamauchi N, Ueda N and Sone T. Effect of molybdenum on hardness of low-temperature plasma carburized austenitic stainless steel. Surface and Coatings Technology. 2007; 201(9-11):5102-5107. http://dx.doi. org/10.1016/j.surfcoat.2006.07.127.

17. Sun Y. Kinetics of low temperature plasma carburizing of austenitic stainless steels. Journal of Materials Processing Technology. 2005; 168(2):189-194. http://dx.doi.org/10.1016/j. jmatprotec.2004.10.005.

18. ASM Handbook Committee. ASM Handbook: heat treating. Ohio: ASM International; 1991. ASM Handbook, v. 4. 